\title{
The Worshipful Company of Goldsmiths
}

\author{
L. B. Hunt \\ Johnson Matthey \& Co., Limited, London
}

One of the oldest and greatest of the Livery Companies of London, the Worshipful Company of Goldsmiths has a long and continuous history of devotion to the goldsmiths' craft. It still binds apprentices as in the Middle Ages to ensurè high standards of workmanship, administers the hall-marking laws and safeguards the quality of the national coinage, while in modern times it takes an active part in bringing the science of metallurgy to bear upon the work of the industry it so nobly represents.

By the beginning of the twelfth century voluntary associations or fraternities of master craftsmen, banded together for mutual protection, had become established in many towns and cities of Western Europe. A rapid growth in population, a general expansion in trade and the development of villages into towns - often with the workers in a particular craft living in the same street - all tended to encourage this kind of organisation, which combined a charitable and often a religious element with a system of apprenticeship to ensure that only those qualified to practice their craft were allowed to do so. Over the centuries many of these fraternities or gilds have disappeared, but in England quite an astonishing number survive as the Livery Companies of the City of London.

Almost the oldest of these is the Worshipful Company of Goldsmiths, and it is one of the very few such successors to the original gilds that can show a record of continuous activity in the protection and welfare of its craft.

No written records exist to establish the date of formation of the Goldsmiths, but that they constituted a fairly wealthy organisation of some importance and long standing well before 1180 is certain from an entry in the Pipe Rolls of Henry II. In that year the Gild of Goldsmiths was fined the considerable sum of 45

The coat of arms of the Worshipful Company of Goldsmiths shows in the first and fourth quarters a leopard's head - the first hall-mark instituted in 1300 by Edward $I$ - and in the second and third quarters a covered cup with two round buckles or brooches to represent the workers in large pieces of plate and in smaller items of jewellery respectively. The Company had displayed arms certainly as long back as 1470 , but this is the earliest representation in their possession, taken from their Book of Ordinances of $\mathbf{1 5 1 3}$ marks on the score of their having been formed without the permission of the Crown (1). Despite this apparent royal disapprobation, the leading mastergoldsmiths of the time were then - and for centuries to come - without doubt of vital importance both to the Crown and to the governance of London.

The fineness of the coinage was closely interwoven with that of the wares made by the practusing goldsmiths, if only to prevent the melting down of coin, and to keep the two firmly in line the skills and knowledge of the organised goldsmiths were essential

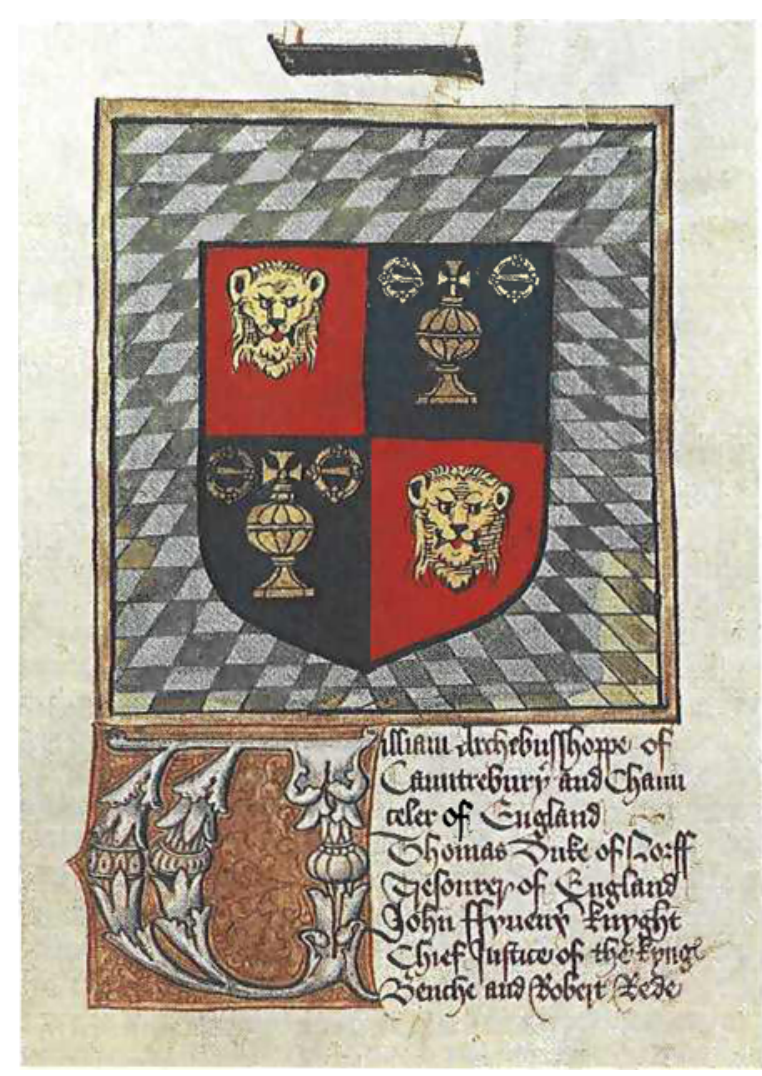


to the Exchequer and to the mints, of which there was still quite a number up and down the country until the end of the twelfth century. The fire assaying of the coinage probably goes back to the time of the Norman Conquest, but the first record we have of this long established procedure comes just before Henry II - the great architect of a stable and prosperous England following the anarchy and misrule of the previous twenty years - initiated a complete recoinage of the silver pence in 1180. A year or two earlier his Treasurer, Richard Fitz Nigel, compiled a practical treatise, Dialogus de Scaccario - Discourse on the Exchequer - which included an account of the assay:

'The pence are then again counted in the presence of the Melter and of the persons sent by the Barons, and are handed to the Melter. He takes them, counts them with his own hands, and arranges them in an ash cupel in the furnace. He then, following the rules of his art, melts them into an ingot, fusing and refining the silver.' (2)

This 'trial' of the coinage was to develop gradually into a much more elaborate and dignified procedure in which the Worshipful Company of Goldsmiths came to play the principal role, but in the meantime their leading members, many of them already aldermen, were acquiring positions of great authority in London. When Richard I, before he left for the Second Crusade at the end of 1189 after only four months in his realm, instituted the office of Mayor of London, together with two sheriffs, it was a Goldsmith, Henry Fitzailwin, who first held this high office (3) and continued to hold it until his death in 1212. From then onwards many Goldsmiths have held office as Mayor (the title of Lord Mayor did not come into use until the 16th century) and as sheriffs, and it was men of this calibre who were not only prominent in their trade and in its regulation but were in close association with the court and the Exchequer as well as with the Mint, which by 1300 was virtually confined to London.

By 1247 , in the reign of Henry III, it had become necessary to undertake a complete re-coinage of the silver penny which had survived for some sixty seven years and four reigns and had suffered intolerably from the practice of clipping. In the following year, before this massive operation was complete, the mayor and citizens of London were commanded to choose

'twelve of the more discreet and lawful men of our city of Lon don and join them with twelve good goldsmiths of the same city . . to examine upon oath both the old and the new money of our land, and make provision how it may be bettered; and that it is made of good silver, and that it is lawful and for the good of the realm' (4).

The assay was carried out in the presence of the King, the King's Council and the Warden of the
Mint. At this time there was no gold coinage in England, but in 1257 Henry III introduced a 'penny' in fine gold; this was speedily withdrawn, however, after protestations from the citizens of London and the reappearance of gold coinage was delayed for many years.

A more public trial of the money took place in 1279, when Edward I commanded the barons of the Exchequer to take with them Gregory de Rokesle - a Goldsmith for many years Mayor of London and from 1279 to 1291 both Warden of the Mint in the Tower of London and Keeper of the Exchange - and 'to make the assay in such manner as the King's Council were wont to do' (5). The assay was again carried out in the presence of the King and his Council, and this formal trial was now made a regular obligation, sample coins to be set aside in the Pyx chest. The word 'Pyx' is of Roman origin, stemming from the Greek 'Puxis' - a box - and the Pyx chests containing the sample coins for assay were kept in the Pyx Chapel of Westminster Abbey along with the standard trial plates of coin fineness until well into the nineteenth century.

\section{Control of the Coinage and of the Goldsmiths Craft}

In 1299 Edward I completed a further re-coinage, and a year later promulgated a set of regulations covering the work of the goldsmiths. They were not to use any gold which was 'worse than the touch of Paris' (19 1/5 carat; reference to a foreign standard was necessary because there were then no English gold coins) and the wardens of the Goldsmiths Company were to

'go from shop to shop amongst the workers, assaying that their gold be exactly like the aforesaid touch, and if they find any piece worse than the touch, that piece shall be forfeit to the King.'

Silver articles, which were to be of the sterling standard of finess, were similarly not to leave the maker's shop before they had been assayed by the wardens and marked with the leopard's head. This was the first hall-mark, known initially as the King's mark, and it was used alone until 1363, later when other assay offices were established, becoming the mark for wares assayed in London where it is of course still in use.

Thus the practices of the trade of the goldsmith were placed firmly and legally under the control of the wardens, but unfortunately the succession of Edward II on his father's death in 1307 opened a period of uncertainty, with much clipping of coins, the importation of inferior foreign coins and an insufficient supply of money from the Mint. For some years the Goldsmiths suffered a degree of uneasiness, but when their opportunity came they acted with great alacrity. 


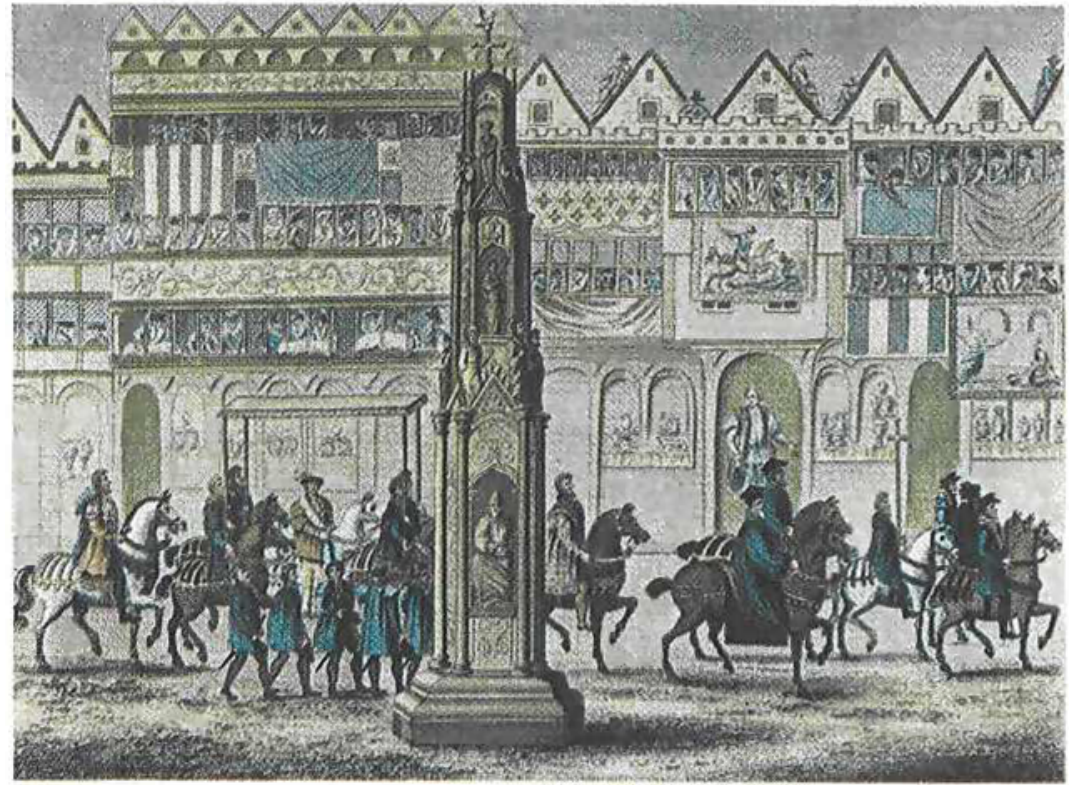

Goldsmiths' Row in Cheapside, then the most splendid street in London, and often known simpIy as "The Street" as depicted in 1547, with part of the coronation procession of Edward VI. In his 'Survey of London', published in 1598, John Stow described the building of 'the most beautiful frame of fair houses and shops within the walls of London or elsewhere, built by Thomas Wood, goldsmith and one of the sheriffs of London, in the year 1491. Reporting home to his senate in 1497, the Venetian ambassador wrote: 'In one single thoroughfare, named The Street, leading to St. Paul's, there are fifty two goldsmiths shops. that in all the shops in Milan, Rome and Venice and Florence pui together, I do not think there would be found so magnificent an array

When in 1327 Edward II was deposed he was succeeded on January 25th of that year by his 14 year old son as Edward III, the coronation taking place on February 1st. The Goldsmiths immediately petitioned the King, and by March 13th they had received the first and most important of their Royal Charters.

This largely confirmed their position and their powers under the statute of 1300 , but the important difference was that the charter was royal rather than derived from merely civic authority. There was also a provision that

'no one who claims to belong to the said craft shall hold shop save in Cheap in order that men may see their work is good and suitable'

while provincial goldsmiths were required

'to make and keep the same ordinances as they of London do'.

Cheapside, near St. Paul's Cathedral, had for long been the goldsmiths' quarter, and it was close by here, in Foster Lane, that the Company acquired land in 1339 on which to build themselves a Hall. The project was not completed, however, until 1366, but then the Goldsmiths could take a great pride in having a home not yet possessed by any other craft as well as a visible sign of their importance.

\section{The First Hall-Marks}

Meanwhile, in 1363, the Goldsmiths received, under a Statute of Edward III, a further confirmation and amplification of their functions. Included in this enactment was the provision that

"every master goldsmith shall have a mark by himself, and the same mark shall be known by them who shall be assigned by the King to survey their work and alloy. and after the assay made, the surveyor shall set the King's mark, and after the goldsmith his mark, for which he will answer.'
The need for yet another charter arose during the reign of Richard II. The city of London had incurred the King's displeasure, the mayor and sheriffs were dismissed, and the city was fined the enormous sum of 2,100000 , but a reconciliation was arranged, the fine remitted and the powers of the city restored. The Goldsmiths again acted speedily, and in 1393 received a new charter under which they were to be

'a perpetual community ..to elect yearly out of themselves four wardens to oversee, rule and duly govern the said craft and community and all and every member thereof' (6).

These rights and privileges were confirmed successively by Henry IV after the dethronement of Richard II, by Henry V and VI, and then by Edward IV early in his first period as king during the Wars of the Roses, his letters Patent of 1462 granting the Company the title of "The Wardens and Commonalty of the Mystery of Goldsmiths of the City of London'.

In 1478 - just 500 years ago - two important moves were made by the Goldsmiths. To avoid the troublesome tasks imposed upon the wardens by their duty to visit the workshops, a full time salaried assayer was appointed, sworn to make true assays of the gold and silver brought to Goldsmiths Hall "without favour, affection, hate or evil will to any party'.

Secondly a further hall-mark, the date letter, was now introduced to supplement the leopard's head and the maker's mark. Beginning with a capital A and proceeding in alphabetical order to $\mathrm{U}$, omitting $\mathrm{J}$, before starting again on the following May 19, the day of installation of new wardens and the day on which the Goldsmith's patron saint, St. Dunstan, was annually celebrated. The form of the new mark was changed every twenty years by using different type and by varying the shape of the shield surrounding 
the letter. Thus the complete system of hall-marking, probably the oldest form of consumer protection in the world and a simple method of identification for dealers and collectors of gold and silver, has a continuous and continuing history of five centuries.

At the same time the standard of fineness for gold wares was reduced by statute from the Paris standard of $191 / 5$ carat to 18 carat, where it remained until it was raised again to 22 carat in 1576 . This high value was retained until 1798 when the use of 18 carat was re-introduced as an optional standard with its own mark, a crown and the figure 18 .

The Elizabethan period was a most prosperous time for the London goldsmiths; great quantities of gold were arriving from the Spanish mines in South and Central America, and the Queen and her court were avid buyers of both jewellery and a great variety of articles in silver, silver-gilt and gold. Just one record of a payment by the Queen to her personal goldsmith a man rejoicing in the name of Affabel Partridge indicates something of the scale of purchases:

'For 3,098 oz, of gilt plate, at 7s.6d. the oz., which was given away in New Years' gifts, $\& 1161$ 17s 93/4d.'

But the country itself was impoverished both by the gross debasement of the coinage under her father Henry VIII, and by steeply rising prices. The Queen's financial adviser, Sir Thomas Gresham, tendered advice which has a certain twentieth century ring about it:

'An it please your majesty to restore this your realm into such estate as heretofore it hath been first. Your Highness hath none other ways, but when time and opportunity serveth, to bring your base money into fine, of eleven ounces fine, and so gold after the rate. to come in as small debt as you can beyond seas . to keep your credit, and specially with your own merchants, for it is they who must stand by you, at all events, in your necessity."

Queen Elizabeth promptly accepted this advice, and in 1560 gold coins of both fine and 22 carat were minted. The two gold trial plates made for the Trial of the Pyx are illustrated here, while an account of the trial later in the same period records for the first time the official role to be played from then onwards by the Worshipful Company of Goldsmiths, although from the wording, and the use of the phrase the King's Standard' later in the manuscript, it is clear that the ceremonial procedure was by no means new. An order drawn up by Sir Richard Martyn, twice Lord Mayor of London and four times Prime Warden of the Goldsmiths' Company, and Master and Warden of the Mint from 1580 to 1617 , lays down the procedure:

'First, the Lord Chancellor or Lord Keeper of the Great Seall for the tyme beinge, and the Treasurer of England, and others of the Counsell, have used to cause to be summoned the Treasurer and all other Officers of the Mynt, and allso the Master and Wardons of the Goldsmyths of London, and xii other of the most wysest and discrete men of that Company, to appear before them in the Starre Chamber. .. The Queen's Remembrancer of the said Court of the Exchequer also to attend with the Record of the olde Assais, and to wright that appertaineth, and to take their verdict.' (7)

The ceremonial form of the Trial of the Pyx continues to this day, although for well over a hundred years the trial has been held in Goldsmiths' Hall instead of at Westminster.

Early in her reign Queen Elizabeth I announced that to make an end of all troubles arising from debased monies, Her Majesty has already begun a coinage of fine money in the Tower of London". These are the two trial plates made at the time, one in 22 carat 916.6 fine) and the other in 23 carat $3 \frac{1}{2}$ grains (994.8 fine). Trial plates were always divided by serrations into separate pieces, to be held by the Exchequer, the Mint and the Goldsmiths Company respectively, so that they could be matched together before the Trial of the Pyx took place. The oldest gold trial plate of which there is any record is still in existence; it was made in 1477 in the reign of King Edward IV

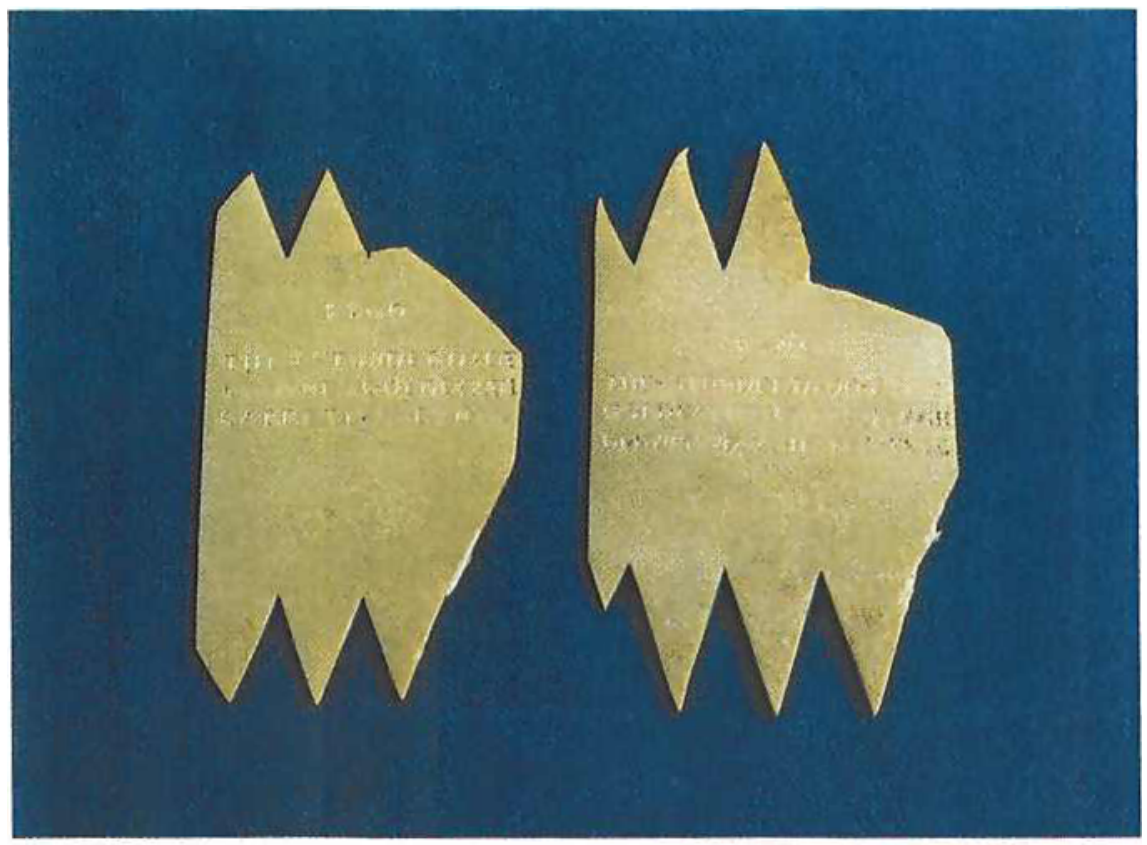




\section{Chrufo-thriambos. Xevis-deraiusor The Triumphes of GOLDE.}

At the Inauguration of $\operatorname{Sir} I_{A} M E s$

PExะ \& R Y N Knight, in the Dignity of Lord Maior of London: On Tuefday, the 29. of OQtober. 16 I 1 .

\section{Performed in the barty loue, and at the charges of the Right Worhipfull, Worthy, and Ancient Company of Gold- Smithes.}

Dewifed and Written by A. M. Cittixen and Draper of London.

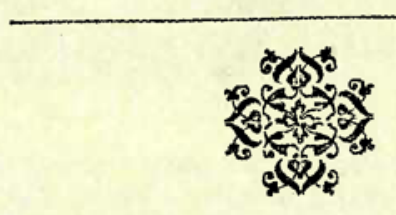

\section{Imprinted by William laggard, \\ Printer to the Honourable Citty of Loadon. 16 II.}

Quite another feature of the London goldsmiths is to be seen during the Commonwealth under Oliver Cromwell and after the Restoration of Charles II the holding and lending of money and the beginnings of the banking system. A number of them had by now been established for sometime in Lombard Street an extension of Cheapside - and it was mainly here that this practice of advancing money began. Sir Thomas Viner, for example, Lord Mayor in 1648 and one of the Goldsmiths' jury elected to make new trial plates in the following year, acted as banker to a number of large estates and advanced substantial loans against the security of valuable plate or property, while his son, Sir Robert, goldsmith to Charles II, followed the same course of business. Samuel Pepys records in his diary on February 1st 1666:

'Thence to Sir Robert Viner's, leaving clear in his hands $£ 2,000$ of my owne money to call for when I pleased.'

Those of the goldsmiths who carried on business in this way naturally issued receipts for deposits of cash, payable on demand, and these, called 'goldsmiths' notes', were often passed from hand to hand as the predecessors of the bank notes issued when the Bank of England was established in 1694 - an innovation somewhat unpopular with the London goldsmiths of the time. None the less a close association with banking and bankers has been preserved to this day.
One of the functions of the Livery Companies was to provide entertainment and pageants for their members, forerunners of the present Lord Mayor's Show. In 1611 a Goldsmith, Sir James Pemberton, was installed as Lord Mayor and a pageant, Chruso-thriambos, or The Triumph of Gold, was written and produced by Anthony Mundy, a minor Elizabethan playwright, at the request and at the expense of the Goldsmiths' Company. Five hundred copies were printed as souvenirs of the occasion, the text setting out to glorify the City, the Company and the Lord Mayor

But before this minor set-back a major disaster had occurred. Within only a few months of Pepys putting his money on deposit with Sir Robert Viner he was hurrying to Whitehall to bring Charles II the news of the 'Great Fire' which in five days destroyed virtually all of the City of London, by far the greatest town in the kingdom and the source of half its wealth. Goldsmiths' Hall was left a smoking shell, the treasured plate that was rescued having to be sold to help towards the costs of rebuilding.

This impoverishment of the Company inevitably reduced the scale of its charitable benefactions, and although by great efforts the Hall was restored within three years, it was a long time before the vigorous control of the craft was as effectively enforced as it had formerly been. Also the trade began to spread into new suburbs outside the city walls, notably into Clerkenwell, from whence stemmed the nineteenth century move to Hatton Garden.

The rights and duties of assaying the work of the goldsmiths and silversmiths were nevertheless quietly continued, while on somewhat infrequent occasions Trials of the Pyx were held and new trial plates were prepared and certified. On only one occasion did disagreement and acrimony arise - during the long period when Sir Isaac Newton was Warden and later Master of the Mint. At the Trial in 1710 the jury of Goldsmiths rejected the gold coins as below standard by just over 1 part in 1000 , owing, in Newton's opinion, to recent improvements in refining the gold used for the trial plate. The Mint officials, led by Sir Isaac, were so vociferous in their protests that they were ejected from the assembly (8). This trial plate was then abandoned and at the next trial in 1713 the coin was tried against the plates made in 1660 and 1688.

The Industrial Revolution in England in the latter part of the eighteenth century was not a feature of life in London but only of the more northern parts of the country, although one of its major effects was to reduce the relative importance of the capital as a commercial centre. One of the principal architects of this radical change in manufacturing was responsible for 
a move which the Goldsmiths' Company regarded as highly detrimental to their interests. Mathew Boulton, the son of a prosperous maker of buttons and buckles in Birmingham, extended the family business he had inherited in 1759 by building a large factory for the production of articles in gold, silver and other metals of good design and quality, and found that he had to send his precious metal products some seventy miles to Chester, where an Assay Office had been established for very many years. The consequent delays and expense prompted Boulton to seek support from others in the trade and from members of the government and of the local nobility - as well as from the King, George III - in sponsoring an Act of Parliament to authorise an Assay Office in Birm. ingham. In this project he was also supported by the plate workers of Sheffield, who asked 'to go hand in hand with you to Parliament and to be comprehended in the same Act' (9).

Boulton's energy and enterprise were immense, as may be gathered from a letter of his to his agent Wendler written in 1767 :

'I should be glad to work for all Europe in all things that they may have occasion for - gold, silver, copper, plated, gilt, pinchbeck, steel, platina, tortoiseshell, or anything else that may become an articele of general demand.' (10)

The reaction from London was predictable and swift. Led by the Prime Warden, Peter Floyer, a gold refiner in a substantial and old established business, and with the full authority of the Wardens and Assistants of the Company of Goldsmiths, a counterpetition was presented to Parliament claiming rather immoderately that such a departure

\footnotetext{
'might open a door to deceit and uncertainty. and tend to destroy that credit and reputation which the Goldsmiths' manufactury in these kingdoms has justly acquired."
}

Further petitions and counter-petitions followed, but the Bill was finally passed in 1773, giving both Birmingham and Sheffield the right to assay and mark silver wares only. Similar rights for gold articles were not granted however until 1824 in Birmingham and 1904 in Sheffield. Despite the legal battle and the charges and counter charges that had marred relations for many months, once the Act was passed friendly relations were immediately established between the Goldsmiths' Company and the representatives of the two provincial cities - a happy state of affairs that has continued to this day.

The early years of the nineteenth century were clouded by the Napoleonic Wars, but their eventual conclusion at the battle of Waterloo involved the Goldsmiths' Company in a most unusual event. Napoleon's escape from Elba and his return to France in March 1815 necessitated the maintenance of a considerable force of British troops in that country, and they had to be paid. With the consent of Louis XVIII large quantities of Louis d'or, faithfully reproducing the fineness and weight of the originals, were ordered to be struck at the Mint, and samples were placed in the Pyx along with British coins. A special jury was then summoned to Goldsmiths' Hall to hold a trial of these French coins, not against trial plates but against genuine gold coins of France supplied by the French Ambassador which were melted down and used as the standard.

Until 1854 the standard for gold plate and jewellery remained at 18 carat, but for some few years jewellery manufacturers had been seeking a greater latitude, believing that a market existed for less expensive items. Their expressed wishes were met by the introduction of not one but three additional standards, 15,12 and 9 carat. This rather obviously led to a considerable growth in demand for the lowest quality, and today by far the largest proportion of the gold wares submitted to Goldsmiths' Hall are manufactured in a range of 9 carat alloys despite the fact that these contain only 37.5 per cent of gold by weight (and something less than 20 per cent by volume!), the remainder consisting of copper, silver, zinc and other base metals. The 12 and 15 carat standards were eventually replaced by 14 carat in 1932 .

The standard for coinage remained at 22 carat, but it was beginning to be realised that in the melting and casting of alloys of gold with copper or silver considerable segregation occurs during solidification. A

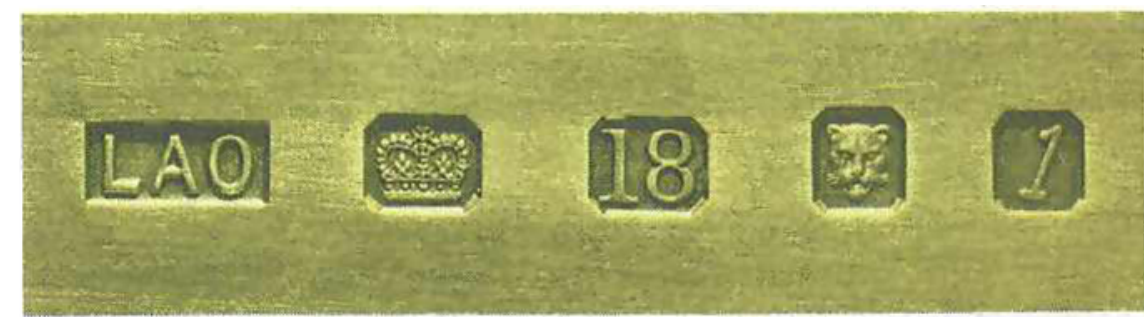

A set of hall-marks on a piece of gold plate. First comes the maker's mark, ordained in 1363 by Edward III, followed by the standard marks for gold, the crown with the 18 carat mark, then the leopard's head, established by Edward I in 1299, and finally the date letter, in this case for 1966. Date letters were introduced just 500 years ago in 1478 


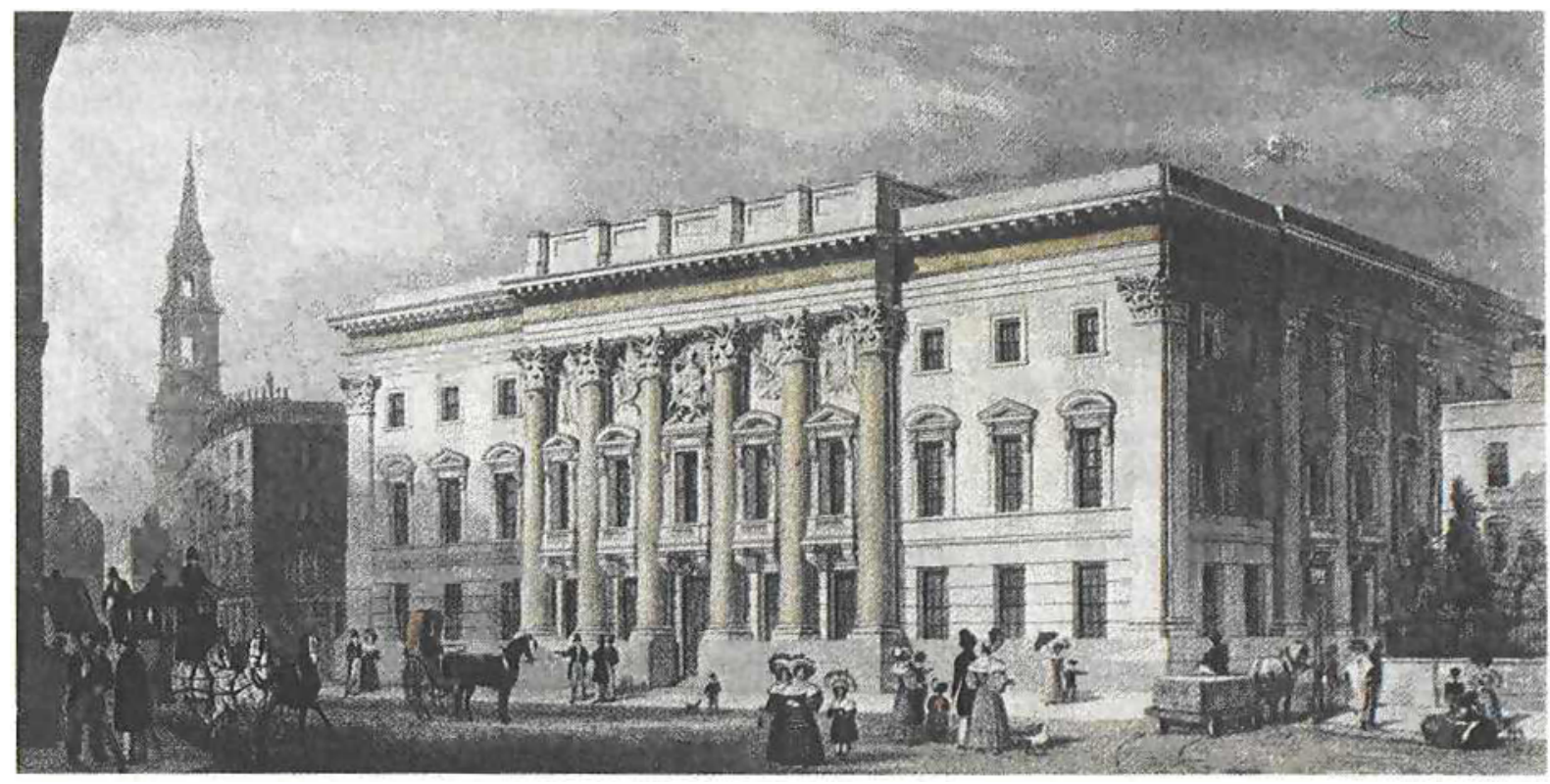

In 1339 the Goldsmiths' Company bought land in Foster Lane, just off Cheapside, on which to build themselves a Hall. This engraving by Thomas Shepherd shows the present Hall, the third to be built on the same site in 1835. Today Goldsmith' Hall is the very active centre of the craft, where the Company still binds apprentices and admits them as Freemen after their masterpieces have been presented for examination by the Wardens, where the statutory assaying and the administration of the hall-marking laws are still conducted without reward or profit, and where in more recent years research projects are either undertaken or sponsored on the metallurgy and fabrication of gold and its alloys

trial plate made by the Goldsmiths' Company in 1829 was found to be 1.3 parts per thousand below the prescribed standard, but was nevertheless used in the Trials of the Pyx for the next forty years (11).

In 1870 the Royal Mint was reorganised under the Coinage Act of that year, the office of Master was vested in the Chancellor of the Exchequer for the time being, with a Deputy Master as the executive superintendent, and the post of Chemist of the Mint was established. By great good fortune the first holder of this office was a young man of 27 named William Chandler Roberts who had been for five years since leaving the Royal School of Mines the private assistant to Professor Thomas Graham, the great chemist who had been Master of the Mint from 1856 until his death in 1869. At the same time it was stipulated that the Trial of the Pyx should be held yearly in Goldsmiths' Hall.

\section{The Beginning of Physical Metallurgy}

Roberts, later to be known as Sir William RobertsAusten and as one of the principal pioneers in the new science of physical metallurgy, quickly came to the conclusion that there was always the possibility of inconsistency and error in the alloy trial plates, and that trial against a test piece of pure gold would be preferable. The Goldsmiths' Company also considered that trial against a fine gold plate would be better and he therefore prepared, in 1873, a more homogeneous 22 carat gold plate containing only cop- per as the alloying element and a supplementary plate of carefully purified gold, made by reducing gold chloride with oxalic acid, melting the precipitate and heating in vacuum. Of this he wrote:

'I have not been able to prepare, or to obtain from any source, gold of greater purity, even in small quantities.' (12)

The outcome of this work became the incentive for a series of fundamental researches, many of them concerned with the metallurgy and the physical properties of gold and its alloys, which he carried out over the next thirty years. In 1880 he was appointed Professor of Metallurgy at the Royal School of Mines, but continued in office at the Mint, where all his researches were conducted, including the famous investigation of the effects of small additions of a number of alloying elements on the tensile strength and elongation of gold in relation to their atomic volume (13) and the discovery of the purple alloy of gold and aluminium so well known - if so unwelcome - to electronic engineers to this day.

While Roberts-Austen (as he became in 1885) was helping to lay the foundations of physical metallurgy in his laboratory at the Royal Mint two other men had embarked along a similar course at Cambridge, an event which was to influence both the Worshipful Company of Goldsmiths and the University in a new and important direction. In a small room at Sidney Sussex College, fitted up as a chemical laboratory, 
Francis Henry Neville and his younger friend Charles Thomas Heycock, working in the early mornings and late at night - they were both lecturing and tutoring by day - began in 1888 a series of researches on gold alloys that were to establish them also as pioneers. Starting with alloys of gold and sodium - their only means of temperature measurement at that time being a mercury thermometer - they progressed to alloys of higher melting point when the platinum resistance thermometer was developed by Professor H. L. Callendar and their own close colleague Professor E. $\mathrm{H}$, Griffiths, and by 1895 had published a number of freezing points of the metals, including a figure for gold of $1061.7^{\circ} \mathrm{C}$, astonishingly close to the modern value. But their use of the microscope and of $\mathrm{X}$-ray examination, coupled with freezing point determinations on the range of alloys, initiated the now standard technique of establishing constitutional diagrams. Their own work, published in a long series of papers given to the Royal Society and the Chemical Society between 1889 and 1914, included the first comprehensive studies of the aluminium-gold, tingold, silver-copper and copper-tin systems, described a few years later by the great metallurgist Walter Rosenhain as 'perfect examples of such investigations, particularly as far as accuracy and completeness are concerned' (14). Roberts-Austen was deeply interested in their work, and on at least one occasion invited them to collaborate with him in experimental work at the Royal Mint.

\section{The Goldsmiths' Readership in Metallurgy}

Heycock and Neville turned to George Matthey for support - their work was entirely self-financed and he freely lent them considerable quantities of gold and had numerous assays carried out on their alloys. This friendship grew; all three were Fellows of the Royal Society, and George Matthey, who combined great scientific talent with a shrewd business sense as the leading refiner of gold and platinum, took the chair at momentous meeting at the Royal Institution one evening in 1897 when Heycock gave an account of his and Neville's work and showed, for the first time, microradiographs of the structure of goldsodium alloys - only two years after the discovery of $\mathrm{X}$-rays. It was to develop into a long and fruitful association with the Goldsmiths' Company in which Matthey was already an elder statesman, having been a member of the Court since 1865 and Prime Warden in 1872 and again in 1894 . It was to lead, in 1908 , to the Goldsmiths' Company providing finance 'for the purpose of founding and endowing a Readership in Metallurgy, such Readership to be associated with the name of the Company', in the University of Cambridge. Neville was about to retire at this time, and

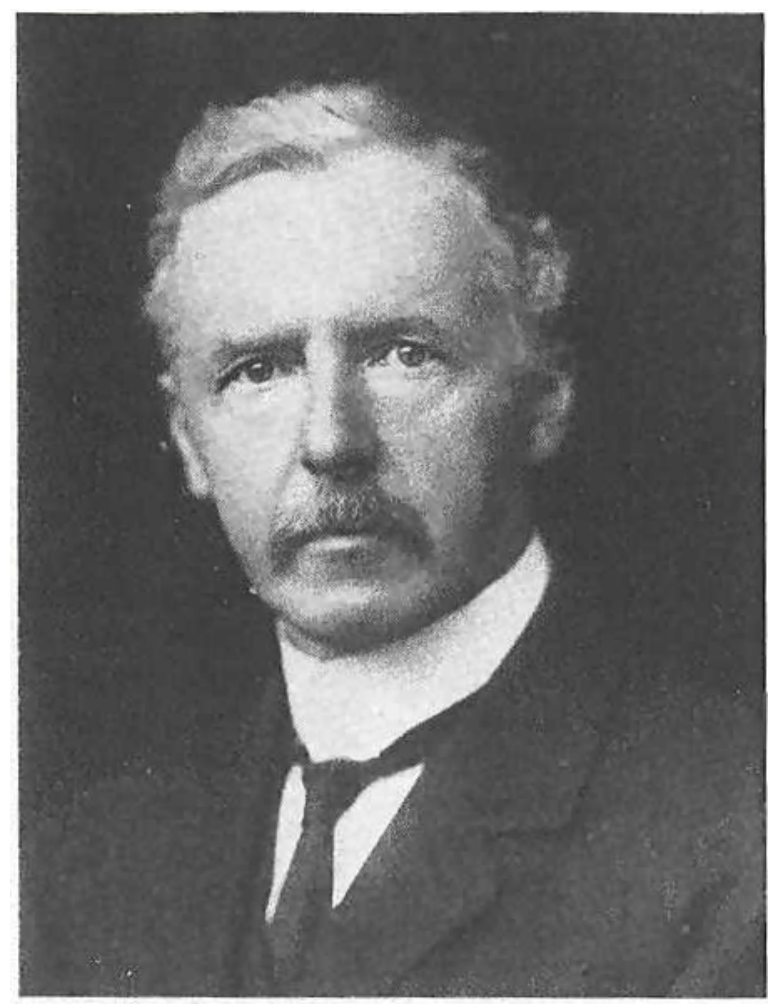

Charles Thomas Heycock

After a long series of brilliant researches on the constitution of a number of gold alloys, carried out with his friend F. H. Neville at their own expense, Heycock was appointed Reader in Metallurgy in the University of Cambridge, a post endowed by the Goldsmiths' Company and an appointment which brought about the first official recognition by the University of metallurgy as a subject of study. He was elected Prime Warden in 1922, and on his death in 1931 the Company provided a further endowment for a professorial chair. The Goldsmiths' Professorship of Metallurgy has since been held by four distinguished scientists

the very obvious choice of Heycock to hold the appointment was duly made by the University authorities who then, for the first time, officially recognised metallurgy as a suitable subject for study. George Matthey immediately proposed Heycock for the Freedom and Livery of the Company, and he was elected to the Court in 1913, his fellow members of the Court being rather astonished to find that the scientist now in their midst was in fact a most cultured and sociable companion!

By 1919 the number of Heycock's students had grown substantially, and he sought further support from the Goldsmiths' Company. They responded generously, and in the following year built and equipped a new metallurgical laboratory which was official- 


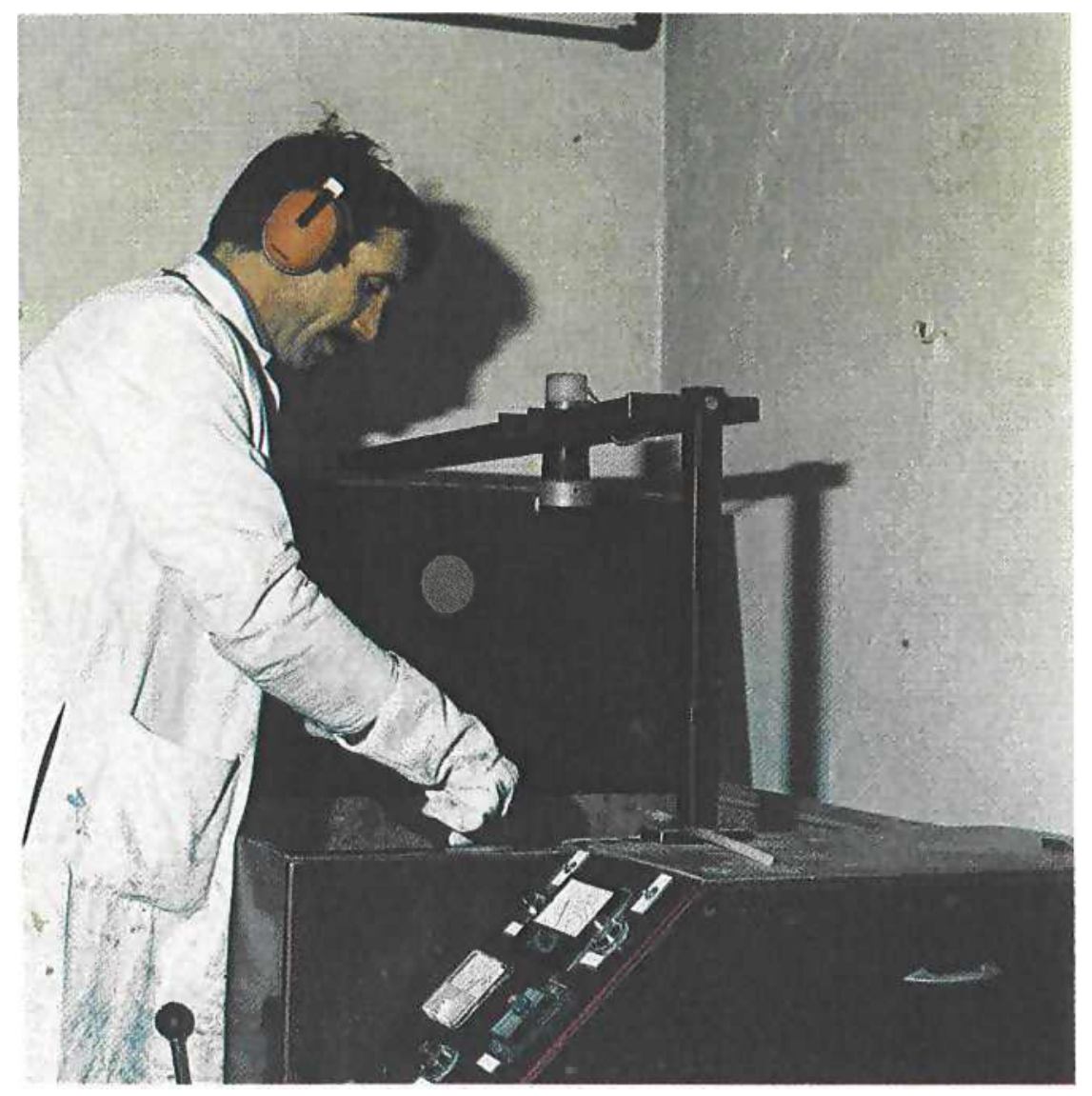

Differences in the alloying constituents of carat gold alloys for investment casting may have a significant effect on their ability to fill an intricate mould, and one of the research projects being undertaken by the Technical Department of the Goldsmiths" Company is a study of the fluidity of such alloys. Melting temperature is controlled by a radiation pyrometer, and the melt is injected into a mould containing a very long and narrow spiral cavity. The length of the casting obtained gives a measure of the relative fluidity of the alloy

ly opened by the then Vice-Chancellor, the famous physicist Sir J. J. Thompson.

In 1920 Heycock was awarded the Davy Medal of the Royal Society for 'his work on the composition and constitution of alloys' while he was elected Prime Warden of the Goldsmiths' Company for the year 1922-23 and served the Company notably in advising on its assay work. The Readership fell vacant on his death in 1931, and the Goldsmiths' Company then decided to increase its financial support. The University was asked to elevate the Readership to a Professorship of Metallurgy, and Dr. R. S. Hutton, the Director of the British Non-Ferrous Metals Research Association, was appointed to the chair as the first Goldsmiths' Professor. As was his predecessor, he was elected to the Livery and later to the Court, becoming Prime Warden in 1942, and similarly gave of his knowledge and experience to the Company's activities. He was succeeded in the chair in 1945 by Professor G. Wesley Austin, in 1958 by Professor (now Sir Alan) Cottrell, and in 1966 by the present occupant, Professor R. W. K. Honeycombe, who heads a large and vigorous Department of Metallurgy with a high reputation in its field and who also now serves on the Court of the Company.

The Goldsmiths' Company had, of course, made many other generous grants for educational purposes, including a number of donations to Imperial College and to the University of London, while in 1959 they made substantial gifts to endow Fellowships in Metallurgy at St. Catherine's College, Oxford, and at the new foundation of Churchill College in Cambridge.

\section{Modern Research Activities}

In 1966 a new phase of activity was initiated with the formation of the Technical Department to provide assistance to the goldsmiths' and silversmiths' industries. Headed by the Director of Research and with a small staff experienced in the relevant manufacturing techniques, the department is able to advise on a wide range of technical problems, while it also undertakes research projects either in the Company's laboratories or by contracting with university departments of metallurgy. These investigations have included studies of gold and silver electroplating, the welding of carat gold alloys, the tarnishing and corrosion of low carat alloys and the development of a technique for measuring the colour of gold alloys, while a substantial expertise has been built up in the field of investment casting - a process nowadays of vital importance to the goldsmith and jeweller. Further expansion of these activities is planned for the future, while the experience and reputation that have 
been built up have put the Goldsmiths' Company into an even stronger position to offer its services to the gold and silverware industries throughout the world.

\section{Eight Centuries of Devotion to the Craft and Industry}

Thus from a medieval gild, originating in the days when master craftsmen first began to employ journeymen and to indenture apprentices, the Worshipful Company of Goldsmiths has a continuous history of eight centuries of devotion and encouragement to its craft, to the preservation of high standards of workmanship, and to the safeguarding of the public's assurance of absolute reliability in the purchase of gold and silver wares. The number of articles submitted to the Company's Assay Office now exceeds one million a month, the assaying and marking needing a staff of over two hundred. The assaying of gold wares is still carried out by the ancient method of cupellation with lead and silver, the lead and base metals being oxidised and absorbed by the magnesia cupel, the silver separated with boiling nitric acid and the remaining gold being annealed and weighed, but modern refinements of the process yield an accuracy of one part in 10000 . The Company has taken a prominent part, in conjunction with the other British assay offices, in establishing international cooperation in hall-marking. As a result there is now an International Convention under which five countries including the United Kingdom mutually recognise common hall-marks applied at authorised assay of fices in any of the other member countries. Four international conferences have been held at Goldsmiths' Hall since 1965, the last one in 1976 being attended by representatives from assay offices in eighteen countries..

The organisation of the Company has remained virtually unaltered over the centuries; the four wardens rise progressively year by year from Fourth, Third and Second Warden to a final year as Prime Warden.
They are elected from the Court of Assistants, numbering twenty-five, themselves chosen from among the 240 liverymen who on admission are formally 'clothed in the livery' in a ceremony which originates from the time of Edward IV who ordained in 1467 that for the election of mayors and sheriffs of London the masters and wardens of the City Companies were "to associate with themselves the honest men of their mysteries and come in their best liveries to the elections' just as they do to this day. The major part of the Company's numbers comprises about 1500 Freemen, about one third of whom have been bound as apprentices at Goldsmiths' Hall before returning after five years to show their masterpieces to the wardens. Others receive their Freedom by Patrimony as the sons of Freemen, or by Redemption, an honour usually reserved for leading members of the trade and for distinguished public figures and scientists.

\section{Acknowledgements}

The author has pleasure in thanking four members of staff of the Worshipful Company of Goldsmiths for information and advice: Miss Susan Hare, Librarian, Mr. J. S. Forbes, Deputy Warden and Assay Master, Mr. Peter Gainsbury;, Director of Research, and Mr. R. J. Barnes, Archivist. He is also grateful to Professor R. W. K. Honeycombe, Goldsmiths' Professor of Metallurgy in the University of Cambridge, for allowing him access to the records of C. T. Heycock's career.

\section{References}

I T. F. Reddaway and L. E. M. Walker, 'The Early History of the Goidsmiths' Company 1327-1509', London, 1975, xix

2 Richard, Son of Nigel, 'Dialogus de Scaccario', translation by C. Johnson, London, 1950, 36.38

3 John Stow, 'A Survey of London', translation by C. L Kingsford, Oxford, 1908, 149 and 306

4 Annual Report of the Mint, London, 1963

5 Thomas Madox, 'The History and Antiquities of the Exchequer of the Kings of England', London, 1711, Vol. I, 291

6 T. F. Reddaway and L. E. M. Walker, Op. cit., 70

7 R. Ruding, 'Annals of the Coinage', 3rd ed., London, 1840, Vol. I, 73

8 E. G. V. Newman, Gold Bull., 1975, 8, (3), 90

9 A. H. Westwood, 'Crown and Anchor', Annual Review, Worshipful Company of Goldsmiths, London, 1972-3, 23

10 Samuel Smiles, 'Lives of Boulton and Watt', 1865, 172

11 J. H. Watson, 'Ancient Trial Plates', London, 1962, 37

12 W. C. Roberts, 7. Roy. Soc. Arts, 1884, 32, 804, 835, 881, 91

13 J. C. Chaston, Gold Bull., 1977, 10, (1), 24

14 W. Rosenhain, F. Inst. Met., 1909, 1, (1), 207

BY all the trials that have been made, Gold seems the most simple of all substances. Its colour is yellow, it is the most malleable and most ductile of all the metals. It is wholly incapable of rust, and is not sonorous when struck upon. It requires a strong fire to melt it, remaining unaltered in the degree of heat that fuses tin or lead, but running with a less vehement one than is necessary to the fusing of iron or copper.

JOHN BARROW

London, 1756

$A$ New and Universal Dictionary of Arts and Sciences 